\title{
MULTI LEVEL MARKETING PT. HARMONI DINAMIK INDONESIA CABANG CIREBON DALAM PERSPEKTIF HUKUM ISLAM DAN HUKUM POSITIF
}

\author{
Didi Sukardi, Ubaidillah dan Suci Maesaroh \\ Fakultas Syariah dan Ekonomi Islam \\ Institut Agama Islam Negeri Syekh Nurjati Cirebon \\ email: didisukardimubarrak@gmail.com, ubaidillah_firly@yahoo.com dan sucimaesaroh14@gmail.com
}

\begin{abstract}
The era of globalization requires humans to follow the development of the era by facing various kinds of problems. One of them is in the world of economy, that is business. Islam as a universal religion certainly has its own solution for every problem that arises in the life of its people. One of the problems in the business world is the existence of a Multi-Level Marketing business, which currently causes a lot of controversy among the community and even religious leaders. This research uses a qualitative method with case study research. In this study used data collection techniques that include observation, in-depth interviews, and literature review. The results of this study include the system used by the company PT. Harmony Dynamic Indonesia is a pure network system of the sun, which in this system members are given the freedom to develop the network. Based on the fatwa on the guidance of direct selling tiered sharia that there are 12 criteria of the business of MultiLevel Marketing which according to sharia, researchers feel very sorry to have not certified sharia Multi Level Marketing at PT. Harmony Dynamic Indonesia, because of lack of awareness of the owners of stockists throughout Indonesia, given the good system, product and bonus distribution.
\end{abstract}

Keywords: Business Multi Level Marketing, Islamic Law and Positive Law.

\begin{abstract}
Abstrak
Era globalisasi menuntut manusia untuk mengikuti perkembangan zaman dengan menghadapi berbagai macam permasalahan-permasalahnnya. Salah satunya ada pada dunia perekonomian, yaitu bisnis. Islam sebagai agama yang universal tentu memiliki solusi tersendiri bagi setiap permasalahan yang muncul di kehidupan umatnya. Salah satu permasalahan di dunia bisnis tersebut yaitu adanya bisnis Multi Level Marketing, yang saat ini banyak menimbulkan kontroversi di kalangan masyarakat bahkan pemuka agama. Penelitian ini menggunakan metode kualitatif dengan jenis penelitian studi kasus. Dalam penelitian ini digunakan teknik pengumpulan data yang meliputi observasi, wawancara mendalam, serta kajian literatur. Hasil dari penelitian ini antara lain; sistem yang digunakan oleh perusahaan PT. Harmoni Dinamik Indonesia ialah system network murni atau matahari, yang manadalam system ini anggota diberikan kebebasan untuk mengembangkan jaringannya. Berdasarkan fatwa tentang pedoman penjualan langsung berjenjang syariah bahwa terdapat 12 kriteria bisnis Multi Level Marketing yang sesuai syariah, peneliti merasa sangat menyayangkan dengan belum bersertifikasi syariahnya Multi Level Marketing di PT. Harmoni Dinamik Indonesia ini, karena kurang kesadaran dari para pemilik stokis di seluruh Indonesia ini, mengingat sudah baiknya sistem, produk dan pembagian bonusnya.
\end{abstract}

Kata Kunci: Bisnis Multi Level Marketing, Hukum Islam dan Hukum Positif. 


\section{PENDAHULUAN}

Kebutuhan hidup manusia yang semakin meningkat menuntut kita untuk melakukan suatu hal untuk memenuhi kebutuhan tersebut, termasuk di dalamnya perekonomian. Salah satu upaya untuk memenuhi kebutuan tersebut ialah dengan berbisnis. Bisnis merupakan suatu aktivitas yang sudah tak asing lagi dijalankan pada era modern ini, dan dilakukan pada semua kalangan mulai dari ibu rumah tangga, artis, pendakwah, hingga pelajar dan mahasiswa. Jika berbicara soal bisnis, maka tak lepas pula kita membahas mengenai marketing. Suatu usaha atau bisnis tidak akan berjalan dengan baik tanpa adanya suatu sistem marketing yang baik pula. Seperti yang dipaparkan oleh pakar marketing ternama Don Failia yang membagi marketing menjadi tiga bagian, yaitu: (a) Retail (eceran), (b) Direct Selling (penjualan langsung kepada konsumen), (c) Multi Level Marketing (MLM).

Bisnis dalam syari'ah Islam pada dasarnya termasuk kategori mu'amalah yang hukum asalnya adalah boleh selagi tidak ada dalil yang mengharamkannya. Multi Level Marketing adalah sebuah sistem pemasaran modern melalui jaringan distribusi yang dibangun secara permanen dengan memosisikan pelanggan perusahaan sekaligus sebagai tenaga pemasaran.Dengan kata lain, dapat dikemukakan bawa Multi Level Marketing adalah pemasaran berjenjang melalui jaringan distribusi yang dibangun dengan menjadikan konsumen sekaligus sebagai tenaga pemasaran. ${ }^{1}$

Berkembangnya model marketing Multi Level Marketing ini pada dunia bisnis, telah menjadi perhatian tersendiri bagi para ulama untuk mengkaji bagaimana aplikasi pelaksanaannya serta hukum Multi Level Marketing itu sendiri dalam hukum Islam, mengingat tidak ada dalil yang secara gamblang menerangkan tentang bisnis tersebut. Namun, sebagai umat Islam yang menjadi pelaku dalam ber-mu'âmalat kita harus mengetahui bahwa Islam memiliki

\footnotetext{
${ }^{1}$ Ahmad Wardi Muslich, Fiqh Muamalah (Jakarta: Amzah, 2013), 613.
}

prinsip dalam pengembangan dunia bisnis yaitu harus terbebas dari unsur. darâr (bahaya), jahâlah(ketidakjelasan), dan alzulm (merugikan atau tidak adil pada salah satu pihak). Dan bisnis pun harus terhindar dari lima unsur yaitu maisir(judi), gharâr(penipuan), harâm, ribâa(bunga), dan bâtil.

Seiring dengan berjalannya waktu, bisnis Multi Level Marketing tersebut menuai banyak kontroversi baik dari kalangan masyarakat maupun kalangan ulama. Salah satu penyebab bisnis Multi Level Marketing menuai kontroversi adalah sistem kerja Multi Level Marketing yang ternyata tidak sesuai syariah, sistem tersebut bernama skema piramida.Menurut UU No. 7 Tahun 2014 Pasal 9, yang dimaksudkan dengan skema piramida adalah istilah atau nama kegiatan usaha yang bukan dari hasil kegiatan penjualan barang, kegiatan tersebut memanfaatkan peluang keikutsertaan mitra usaha untuk memperoleh imbalan pendapatan terutama dari biaya partisipasi orang lain yang bergabung setelah bergabungnya mitra usaha tersebut. ${ }^{2}$

Maraknya isu negatif tersebut, membuat peneliti merasa tertarik untuk mengkaji lebih dalam mengenai bisnis Multi Level Marketing yang diterapkan oleh sebuah perusahaan. Dalam hal ini ialah sebuah perusahaan Internasional yang besar, yang berada di Indonesia selama kurang lebih 23 tahun dan cabangnya tersebar di seluruh nusantara, yaitu PT. Harmoni Dinamik Indonesia (HDI) yang akan peneliti kaji lebih dalam ialah mengenai 1) Bagaiamana praktik bisnis Multi Level Marketing yang diterapkan PT. Harmoni Dinamik Indonesia (HDI) Cabang Cirebon? 2) Bagaimana status hukum bisnis Multi Level Marketing yang diterapkan PT. Harmoni Dinamik Indonesia (HDI) Cabang Cirebon menurut hukum Islam dan hukum positif?

\section{LITERATURE REVIEW}

\footnotetext{
${ }^{2}$ http://www.kemendag.go.id/undangundang-no-7-tentangperdagangan. Diakses pada tanggal 19 April 2017.
} 
Penelitian mengenai bisnis Multi Level Marketing ini memanglah bukan sesuatu yang baru untuk diteliti. Meskipun demikian, nampaknya belum ditemukan penelitian yang secara spesifik membahas mengenai bisnis Multi Level Marketing di PT. Harmoni Dinamik Indonesia Cabang Cirebon dalam perspektif hukum Islam dan hukum positif. Berikut beberapa karya yang terdokumentasikan terkait permasalahan yang dikaji, yaitu pertama, penelitian yang dilakukan oleh Anis Tyas Kuncoro, ${ }^{3}$ yang mengkaji tentang konsep Multi Level Marketing dalam perspektif ekonomi syariah. Yang mana dalam penelitiannya menyatakan bahwa Multi Level Marketing merupakan bisnis yang luar biasa, bisnis yang akan berkembang dengan pesat yang mana tidak ada satupun marketing sistem yang ada saat ini dianggap mampu menandingi keluwesan, kedinamisan dan kesempatan yang biasa diberikan oleh sistem bisnis $M L M$, baik dari sisi produsen, marketing company maupun dari sisi distributor dan konsumen.

Dan kedua, penelitian yang dilakukan oleh Firman Wahyudi yang mengkaji tentang Multi Level Marketing dalam Kajian Fiqh Mu'âmalah. ${ }^{4}$ Yang mana dalam penelitian tersebut diuraikan bahwa mekanisme operasional pada MLM ini adalah seorang distributordapat mengajak orang lain untuk ikut juga sebagai distributor. Kemudian orang lain itudapat mengajak pada orang lain lagi untuk ikut bergabung. Begitu seterusnya, semua yang diajak dan ikut merupakan suatu kelompok distributor yang bebas mengajak orang lain lagi sampai level yang tanpa batas. Inilah salah satu perbedaan MLM dengan pendistribusian konvensional, seorang agen mengajak beberapa orang bergabung kedalam kelompoknya menjadi penjual atau sales atau wiraniaga.

\footnotetext{
${ }^{3}$ Anis Tyas Kuncoro, "Konsep Bisnis Multi Level Marketing Dalam Perspektif Ekonomi Syariah", Jurnal UNISSULA, Vol. XLV, No.119 (Nopember, 2009): 5.

${ }^{4}$ Firman Wahyudi, "Multi Level Marketing dalam kajian Fiq Muamalah", Jurnal Al-Banjari, Vol. 13, No. 2 (Desember, 2014): 166.
}

Dari kedua topik penelitian yang telah dipaparkan di atas, ternyata belum terdapatnya penelitian mengenai bisnis Multi Level Marketing dari sisi hukum Islam dan hukum positif yang dilakukan secara spesifik dengan metode studi kasus pada sebuah perusahaan. Dengan adanya penelitian ini, peneliti berharap akan menemukan sisi terang dari permasalahan bisnis Multi Level Marketing tersebut dengan menganalisis teori atau ketentuan yang telah ditetapkan secara hukum Islam dan hukum positif terhadap sebuah praktik bisnis Multi Level Marketing yang diterapkan oleh sebuah perusahaan.

\section{METODOLOGI PENELITIAN}

Metode yang digunakan dalam penelitian ini adalah kualitatif dengan jenis penelitian studi kasus. Metode kualitatif yakni salah satu metode untuk mendapatkan kebenaran dan tergolong sebagai penelitian ilmiah yang dibangun atas dasar teori-teori yang berkembang dari penelitian dan terkontrol atas dasar empirik. Jadi, dalam penelitian kualitatif ini bukan hanya menyajikan data apa adanya melainkan juga berusah menginterpretasikan korelasi sebagai faktor yang ada yang berlaku meliputi sudut pandang atau proses yang sedang berlangsung. ${ }^{5}$

Dalam hal ini yang diteliti adalah praktik pada perusahaan PT. Harmoni Dinamik Indonesia dalam menjalankan bisnis Multi Level Marketing (MLM) lalu akan di korelasikan dengan teori yang ada dalam pandangan hukum Islam dan hukum positif. Dengan menggunakan metode kualitatif ini dapat menghasilkan data deskriptif berupa kata-kata tertulis atau lisan dari nara sumber. Pengumpulan data dilakukan dengan cara observasi dan wawancara secara terbuka.

Dalam penelitian kualitatif ini digunakan teknik pengumpulan data yang meliputi observasi, wawancara mendalam serta kajian literatur. Observasi merupakan pengumpulan data dengan cara mengamati

${ }^{5}$ Sudarto, Metodologi Penelitian Filsafat (Jakarta: Raja Grafindo Persada, 1995), 63. 
secara langsung objek yang diteliti di lokasi penelitian.

Penelitian ini sumber data yang digunakan berasal dari sumber eksternal, yaitu sumber data penelitian yang diperoleh langsung dari penelitian. Sedangkan untuk sumber data yang diperlukan ialah data primer dan data sekunder. ${ }^{6}$ Sumber data primer didapatkan melalui wawancara dengan informan, diantaranya yaitu pemilik stokis HDI Cirebon, anggota stokis HDI Cirebon, dan konsumen dari HDI Cirebon. Adapun data sekunder yang digunakan pada penelitian ini ialah berupa skripsi, jurnal, artikel, dan website yang berkaitan dengan bisnis Multi Level Marketing, serta pedoman enterpriser kit PT. Harmoni Dinamik Indonesia.

Metode pengumpulan data yang digunakan peneliti ialah berupa observasi, wawancara dan dokumentasi. Berawal dari peneliti yang melihat langsung atau mengamati aktivitas dari lingkungan kerja PT. Harmoni Dinamik Indonesia Cabang Cirebon. Lalu peneliti melakukan wawancara terhadap pemilik stokis HDI Cirebon, beberapa staff stokis HDI Cirebon, anggota HDI Cirebon yang sudah berpengalaman dan memiliki pengetahuan yang luas terkait bisnis ini dan HDI itu sendiri, konsumen HDI, dan menghadiri beberapa acara yang diselenggrakan oleh pihak perusahaan. Dan yang terakhir dokumentasi, peneliti mencari data terkait permasalahan yang ada berupa catatan dan dokumen-dokumen, brosur dari perusahaan PT. Harmoni Dinamik Indonesia (HDI) Cabang Cirebon.

Setelah beberapa data terkumpul dari hasil observasi dan wawancara, peneliti mengkaji beberapa sumber lain dari buku serta artikel yang digunakan oleh peneliti sebagai landasan untuk memperkuat beberapa pernyataan yang didapatkan dan kemudian peneliti kembangkan sebagai pembahasan dalam penulisan.

\section{KONSEP DASAR}

\footnotetext{
${ }^{6}$ Sugiono, Memahami Penelitian Kualitatif (Bandung: Alfabeta, 2008), 102.
}

\section{Bisnis Multi Level Marketing secara Umum}

Multi Level Marketing berasal dari bahasa inggris, multi berarti banyak, level berarti jenjang atau tingkat, sedangkan marketing artinya pemasaran. Jadi, Multi Level Marketing adalah pemasaran yang berjenjang banyak. ${ }^{7}$ Karena anggota dari bisnis ini semakin banyak sehingga menjadi sebuah jaringan kerja, maka Multi Level Marketing disebut juga network marketing. Dengan kata lain, network marketing yaitu sistem pemasaran dengan menggunakan jaringan.

Multi Level Marketing yang biasa disingkat $M L M$, yaitu suatu pemasaran dengan menggunakan jaringan, jadi MLM sebagai penjualan langsung. Dalam pengertian marketing sebenarnya tercakup penjual. Asosiasi Penjualan Langsung Indonesia (APLI) sebagai wadah persatuan Multi Level Marketing menjelaskan pemasaran berjenjang adalah sistem penjualan yang memanfaatkan konsumen sebagai tenaga penyalur secara langsung. Dalam fatwanya, Dewan Syariah Nasional (DSN) MUI menyebutkan bahwa penjualan langsung berjenjang adalah cara penjualan barang atau jasa melalui jaringan pemasaran yang dilakukan oleh perorangan atau badan usaha kepada sejumlah perorangan atau badan usaha lainnya secara berturut-turut. Di Indonesia, saat ini penjualan langsung atau direct selling, baik yang single level maupun multi level bergabung dalam suatu asosiasi yaitu Asosiasi Penjualan Langsung Indonesia (APLI). Organisasi ini merupakan anggota KADIN bagian dari World Federation Direct Selling Association (WFDSA). ${ }^{8}$

Multi Level Marketing merupakan sistem penjualan yang dilakukan oleh perusahaan yang bergerak dalam industri. Multi Level Marketing hanya menjual produk-produknya secara langsung kepada

\footnotetext{
${ }^{7}$ Andreas Harefa, Multi Level Marketing (Jakarta: PT. Gramedia Pustaka Utama, 1999), 4.

${ }^{8}$ Gemala Dewi, Wirdyaningsih dan Yeni Salma Barlinti, Hukum Perikatan Islam di Indonesia (Jakarta: Kencana, 2006), 182.
} 
konsumen yang sudah terdaftar (member), tidak melalui agen atau penyalur, selain itu perusahaan juga memberikan kesempatan kepada setiap konsumen yang sudah terdaftar (member) untuk menjadi tenaga pemasar atau penyalur. Dengan cara ini, maka konsumen akan berfungsi ganda di mata perusahaan, pertama ia menjadi konsumen dan kadang ia juga menjadi mitra perusahaan dalam memasarkan produknya. ${ }^{9}$

\section{Bisnis Multi Level Marketing dalam Hukum Islam}

Dalam hukum Islam,Pada dasarnya semua bentuk kegiatan bisnis termasuk dalam kategori muamalah yang hukumnya sah dan boleh dilakukan. Hal tersebut sesuai dengan kaidah fiqih berikut:

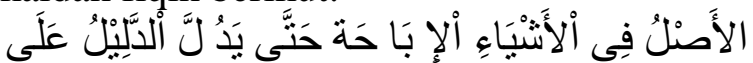

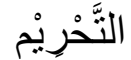

$$
\begin{aligned}
& \text { "Hukum asal dari sesuatu }
\end{aligned}
$$

Berikut adalah beberapa ayat AlQur'an yang dijadikan sebagai rujukan DSN MUI dalam menentukan hukum Multi Level Marketing, diantaranya yaitu:

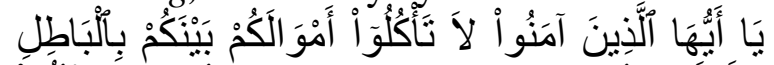

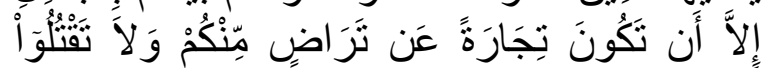

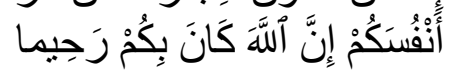

Artinya: "Hai orang-orang yang beriman, janganlah kamu saling memakan harta sesamamu dengan jalan yang batil, kecuali dengan jalan perniagaan yang Berlaku dengan suka sama-suka di antara kamu”."10

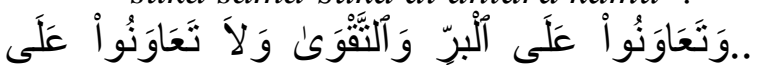

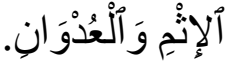

Artinya: "dan tolong-menolonglah kamu dalam (mengerjakan) kebajikan dan takwa, dan jangan tolong-menolong

\footnotetext{
${ }^{9}$ Sofwan Jauhari, MLM Syariah: Buku Wajib Wirausahawan Muslim Praktisi MLM Syariah (Jakarta: Mujaddidi Press, 2013), 143.

${ }^{10}$ QS. An-Nisa (4): 29.
}

$$
\begin{aligned}
& \text { dalam berbuat dosa dan } \\
& \text { pelanggaran". } 11
\end{aligned}
$$

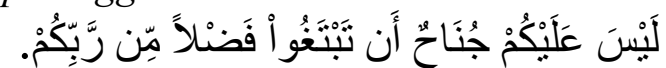

Artinya: "Tidak ada dosa bagimu untuk mencari karunia (rezki hasil perniagaan) dari Tuhanmu". 12

Dan di bawah ini adalah hadits Nabi SAW. yang dijadikan acuan dari bisnis Multi Level Marketing yaitu:

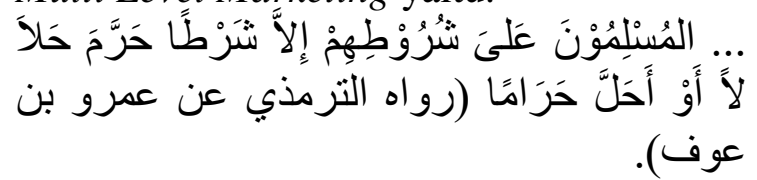

"... Kaum muslimin terikat dengan syarat-syarat mereka kecuali syarat yang mengharamkan yang halal atau menghalalkan yang haram." (HR.Tirmidzi dari'Amr bin 'Auf)

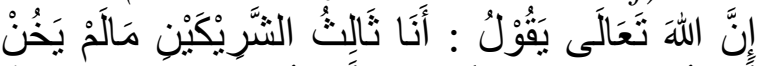

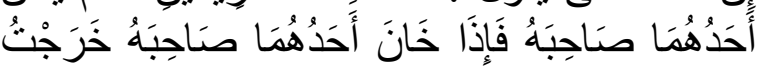

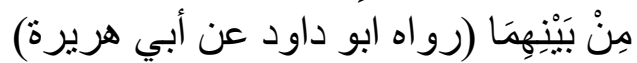
"Allah s.w.t. berfirman, "Aku adalah pihak ketiga dari dua orang yang bersyarikat selama satu pihak tidak mengkhianati pihak yang lain. Jika salah satu pihak telah berkhianat, Aku keluar dari mereka." (HR. Abu Dawud, yang dishahihkan oleh al Hakim, dari Abu Hurairah)

\section{Kriteria Bisnis Multi Level Marketing yang Halal}

Menurut Ma'ruf Amin (Kepala Badan Pelaksana Harian Dewan Syariah Nasional MUI) fatwa MUI terkait Multi Level Marketing syariah memang dibuat ketat. MUI selama ini berpegang pada fatwa MUI nomor 75/DSN-MUI/VII/2009 tentang pedoman Penjualan Langsung Berjenjang Syariah (PBLS) dan No.83/DSNMUI/VI/2012 tentang Penjualan Langsung Berjenjang Syariah Jasa Perjalanan Umrah.

Berikut merupakan kriteria bisnis Multi Level Marketing yang sesuai syariah yang harus memenuhi unsur-unsur sebagai berikut:Adanya obyek transaksi riil yang diperjual belikan berupa produk atau jasa, Produk yang dipasarkan harus halal, thayib

\footnotetext{
${ }^{11}$ QS. Al-Maidah (5): 2.

${ }^{12}$ QS. Al-Baqarah (2): 198.
} 
(berkualitas), dan menghindari syubhat, Sistem akadnya harus memenuhi kaidah dan rukun jual beli sebagaimana yang terdapat dalam hukum Islam, Tidak ada upaya untuk melakukan mark up harga barang yang melampaui batas kewajaran (misal dua kali lipat), sehingga anggota terzalimi dengan harga yang sangat mahal, tidak sepadan dengan kualitas dan manfaatnya, Struktur manajemennya memiliki Dewan Pengawas Syariah (DPS) yang terdiri dari para ulama yang memahami masalah ekonomi, Formula insentif harus adil, tidak menzalimi downline dan tidak menempatkan upline hanya sebagai anggota yang menerima pasif income tanpa bekerja, Pembagian bonus harus mencerminkan usaha masing-masing anggogta, Tidak ada eksploitasi dalam aturan pembagian bonus antara orang yang awal menjadi anggota dengan yang akhir (belakangan), Bonus yang diberikan harus jelas angka nisbahnya sejak awal, Tidak menitikberatkan kepada barang-barang tersier ketika umat masih bergelut dengan pemenuhan kebutuhan primer, Cara penghargaan kepada mereka yang berprestasi tidak boleh mencerminkan sikap hura-hura dan pesta pora karena sikap tersebut tidak sesuai dengan syariah, Perusahaan Multi Level Marketing harus berorientasi kepada kemaslahatan ekonomi umat. ${ }^{13}$

Demikian pula pemberian imbalan atas tenaga dan jasa orang lain, perusahaan Multi Level Marketing biasa memberi reward atau insentif kepada mereka yang berprestasi. Penghargaan semacam ini dibolehkan dalam Islam, namun tetap harus memperhatikan dua kriteria, yaitu :Prestasi penjualan produk, banyaknya down line yang dibina, sehingga ikut menyukseskan kinerjanya.

Sedangkan dari sisi syariah, pemberian insentif harus memenuhi tiga syarat sebagai berikut :Adil. Insentif (bonus) kepada seseorang (up line) tidak boleh

\footnotetext{
${ }^{13}$ Fatwa DSN-MUI tentang 75 Pedoman Penjualan Langsung Berjenjang Sariah (PLBS), dalam www.dsnmui.or.id. Diakses pada tanggal 19 April 2017.
}

mengurangi hak orang lain yang ada di bawahnya (down line), sehingga tidak ada yang dizalimi. Dan terbuka. Pemberian insentif juga harus diinformasikan pada seluruh anggota, bahkan mereka harus diajak musyaarah dalam menentukan insentif dan pembagiannya, lalu berorientasi kepada al-falah (keuntungan dunia dan akhirat). Keuntungan dunia artinya keuntungan yang bersifat materi. Sedangkan keuntungan akhirat bahwa kegiatan bisnisnya merupakan ibadah kepada Allah. ${ }^{14}$

Bisnis Multi Level Marketing yang baik ialah yang mengedepankan unsur-unsur sebagai berikut:Jalinan ukhuwwah Islamiyyah, pembentukan jaringann ekonomi umat, baik berupa jaringan produksi, distribusi dan konsumen sehingga tercipta kemandirian dan kejayaan ekonomi umat, memperkokoh ketahanan akidah dari serbuan ideologi, budaya dan produk yang tidak sesuai dengan nilai-nilai Islam. ${ }^{15}$

\section{Ketentuan Umum Fatwa DSN-MUI Terkait Penjualan Langsung Berjenjang Syariah}

Berikut merupakan beberapa ketentuan umum berdasarkan fatwa DSNMUI tentang Penjualan Langsung Berjenjang Syariah (PLBS), diantaranya yaitu: 1) Penjualan Langsung Berjenjang adalah cara penjualan barang atau jasa melalui jaringan pemasaran yang dilakukan oleh perorangan atau badan usaha kepada sejumlah perorangan atau badan usaha lainnya secara berturut-turut. 2) Barang adalah setiap benda berwujud, baik bergerak maupun tidak bergerak, dapat dihabiskan maupun tidak dapat dihabiskan, yang dapat dimiliki, diperdagangkan, dipakai, dipergunakan, atau dimanfaatkan oleh konsumen. 3) Produk jasa adalah setiap layanan yang berbentuk pekerjaan atau pelayanan untuk dimanfaatkan oleh konsumen. 4) Perusahaan adalah badan usaha yang berbentuk badan

${ }^{14}$ Agustianto, MLM dalam Perspektif Syari'ah, dalam www.iaei-pusat.org. Diakses pada tanggal 19 April 2017.

${ }^{15}$ Ahmad Teguh Wibowo Yusuf, Dialog MLM Syariah (Jakarta: Ahad-Net, 2002), 3. 
hukum yang melakukan kegiatan usaha perdagangan barang dan atau produk jasa dengan sistem penjualan langsung yang terdaftar menurut peraturan perundangundangan yang berlaku. 5) Konsumen adalah pihak pengguna barang dan atau jasa, dan tidak bermaksud untuk memperdagangkannya. 6) Komisi adalah imbalan yang diberikan oleh perusahaan kepada mitra usaha atas penjualan, yang besaran maupun bentuknya diperhitungkan berdasarkan prestasi kerja nyata yang terkait langsung dengan volume atau nilai hasil penjualan barang dan atau produk jasa. 7) Bonus adalah tambahan imbalan yang diberikan oleh perusahaan kepada mitra usaha atas penjualan, karena berhasil melampaui target penjualan barang dan atau produk jasa yang ditetapkan perusahaan. 8) Ighra' adalah daya tarik luar biasa yang menyebabkan orang lalai terhadap kewajibannya demi melakukan hal-hal atau transaksi dalam rangka mempereroleh bonus atau komisi yang dijanjikan. 9) Money Game adalah kegiatan penghimpunan dana masyarakat atau penggandaan uang dengan praktik memberikan komisi dan bonus dari hasil perekrutan atau pendaftaran mitra usaha yang baru atau bergabung kemudian dan bukan dari hasil penjualan produk, atau dari hasil penjualan produk namun produk yang dijual tersebut hanya sebagai kamuflase atau tidak mempunyai mutu atau kualitas yang dapat dipertanggung jawabkan. 10) Excessive mark-up adalah batas marjin laba yang berlebihan yang dikaitkan dengan hal-hal lain di luar biaya. 11) Member get member adalah strategi perekrutan keanggotaan baru yang dilakukan oleh anggota yang telah terdaftar sebelumnya. 12) Mitra usaha (stockist) adalah pengecer atau retailer yang menjual atau memasarkan produk-produk penjualan langsung. ${ }^{16}$

\footnotetext{
${ }^{16}$ Fatwa DSN-MUI tentang 75 Pedoman Penjualan Langsung Berjenjang Sariah (PLBS), dalam www.dsnmui.or.id. Diakses pada tanggal 19 April 2017.
}

\section{Bisnis Multi Level Marketing dalam Hukum Positif}

Dalam tatanan hukum positif, bisnis Multi Level Marketing ini diatur oleh Kementerian Perindustrian dan Perdagangan yang tertuang dalam Undang-Undang Nomor 7 Tahun 2014 tentang perdagangan yang di dalamnya termuat tentang ketentuan umum distribusi barang. Menurut Peraturan Menteri Perdagangan Republik Indonesia No. 13/M-DAG/PER/3/2006 tentang tata cara surat izin usaha langsung, ada beberapa ketentuan pokok yang menjadi acuan dari bisnis Multi Level Marketing yaitu: (1) Berbadan hukum Indonesia yang berbentuk Perseroan Terbatas (PT). (2) Modal sepenuhnya dimiliki oleh Badan Hukum Indonesia dan atau WNI dengan jumlah modal disetor sedikitnya Rp 500 juta. (3) Alamat kantor perusahaan tetap dan jelas. (4) Penjualan dan rekruitmen melalui sistem jaringan. (5) Punya program pemasaran jelas, transparan, rasional, dan bukan jaringan pemasaran terlarang. (6) Memiliki barang dan atau jasa yang nyata dan jelas dengan harga yang layak dan memenuhi standar mutu barang dan atau jasa yang berlaku di Indonesia. (7) Memberikan komisi, bonus atau penghargaan berdasarkan hasil penjualan barang dan atau jasa yang dilakukan oleh Mitra Usaha dan jaringannya sesuai akad yang diperjanjikan. (8) Memberikan informasi yang benar, jelas dan jujur mengenai kondisi dan jaminan barang dan/atau jasa serta memberi penjelasan penggunaan, perbaikan, dan pemeliharaan. (9) Memiliki ketentuan harga barang dan atau jasa yang dijual dalam mata uang rupiah dan berlaku untuk Mitra Usaha dan Konsumen, serta menajamin mutu dan pelayanan purna jual. (10) Ada pembinaan dan pelatihan untuk tingkatkan kemampuan dan pengetahuan Mitra Usaha agar bertindak jujur dan bertanggung jawab. (11) Memberikan kesempatan yang sama kepada semua Mitra Usaha untuk berprestasi memasarkan barang dan/atau jasa. (12) Melakukan pendaftaran atas barang dan/dan atau jasa yang menurut peraturan atau UU 
wajib didaftarkan pada instansi berwenang. ${ }^{17}$

PEMBAHASAN DAN DISKUSI

Praktik Bisnis Multi Level Marketing yang diterapkan oleh PT. Harmoni Dinamik Indonesia (HDI) Cabang Cirebon

Setiap perusahaan Multi Level Marketing memiliki ketentuan masing-masing yang diterapkan oleh perusahaannya, begitupun dengan PT. Harmoni Dinamik Indonesia. Berikut merupakan ketentuan-ketentuannya: 1) Calon member tidak diwajibkan untuk membeli produk terlebih dahulu. Dalam hal ini, perusahaan memberikan kebebasan kepada calon member. Apakah ingin bergabung karena konsumtif (memanfaatkan diskon member), atau karena tertarik dan ingin memanfaatkan bisnisnya (membangun jaringan). 2) Calon anggota yang akan bergabung di HDI, diwajibkan membayar uang sebesar Rp. 110.000 untuk membuat kartu anggota, dan mengganti biaya percetakan enterpriser kit, brosur, CD yang didalamnya berisikan testimoni dan produk HDI, dan yang terakhir untuk jasa konsultasi dokter selama 1 tahun, karena setiap stokis HDI selalu terdapat dokter konsultan. 3) Kartu anggota berlaku selama satu tahun, jika masa berlaku habis dan ingin diperpanjang, member tersebut wajib membayar uang sebesar Rp. 30.000 sebagai biaya administrasi perpanjangan kartu anggota. 4) Apabila seorang member ingin membangun bisnis di HDI ini, maka member tersebut harus menaati peraturan yang ada di perusahaan, salah satunya yakni mengikuti beberapa tahapan training atau pelatihan yang ada di HDI, guna untuk meningkatkan soft skill anggota tersebut. 5) Syarat untuk mendapatkan bonus tiap bulannya (dengan sistem jaringan) ialah dengan adanya sistem tutup poin minimal sebesar 100 - 300 BV tiap bulannya atau sekitar Rp. 300.000 - Rp. 1.000.000. 6)

\footnotetext{
${ }^{17}$ Agustianto, Multi Level Marketing dalam Perspektif Fikih Islam, dalam agustianto@wordpress.com/2007. Diakses pada tanggal 20 juli 2017.
}

Anggota dapat naik level apabila memenuhi kriteria atau target tertentu. 7) Anggota dapat menerima bonus tertentu seperti melakukan perjalanan ke luar negeri, umroh dan berkesempatan naik kapal pesiar apabila telah memenuhi syarat berupa jaringan, omzet, dan waktu tertentu yang telah ditentukan oleh perusahaan. 8) Prosentase bonus yang diterima anggota sesuai dengan yang tertera dalam busines plan dalam enterpriser kit HDI.

Penerapan dari praktik bisnis Multi Level Marketing pada perusahaan PT. Harmoni Dinamik Indonesia ini ialah bahwa setiap anggota diberikan kebebasan untuk mencari downline, tidak dibatasi harus memiliki dua jalur, tiga jalur dan lain sebagainya. Semua anggota di HDI memiliki downline yang bervariasi, ada yang memiliki tiga jalur, lima jalur, sepuluh, dan seterusnya. ${ }^{18}$

\section{Sistem Multi Level Marketing yang diaplikasikan oleh PT. Harmoni Dinamik Indonesia}

Dalam dunia bisnis, termasuk pada bisnis Multi Level Marketing dikenal berbagai macam sistem yang membuat penerapan setiap perusahaan berbeda-beda. Diantara macam-macam sistem pengaplikasian bisnis Multi Level Marketingtersebut. HDI merupakan perusahaan yang menggunakanSistem Network Murni (sistem matahari), yang memiliki kriteria: 1) Sistem ini biasanya mengharuskan untuk membangun lebih dari dua grup besar, bisa tiga, empat dan seterusnya bahkan ada yang mensyaratkan sampai 10 grup besar supaya bisa menempati posisi paling top dalam marketing plan tersebut. 2) Adanya akumulasi pembelanjaan untuk menentukan persentase (\%) dari member tersebut untuk dasar perhitungan bonus. 3) Di sistem ini ada istilah BV, PV untuk perhitungan bonus riilnya, biasanya nilai $\mathrm{BV}$, PV lebih kecil dari nominal rupiahnya. BV atau PV ini sebagai patokan yang akan dikalikan dengan

\footnotetext{
${ }^{18}$ Wawancara dengan Alamsyah BN Hatta, Pemilik Stokis HDI Cirebon, pada tanggal 07 Maret 2018.
} 
persentase member tersebut. 4) Ketika terjadi breakway (peringkat upline setara dengan downline) maka bonus upline turun drastis. 5) Pada sistem ini biasanya menerapkan tutup poin (kewajiban belanja bulanan) sebagai syarat untuk mendapatkan bonus.

\section{Analisis praktik bisnis Multi Level Marketing dalam Perspektif Hukum Islam}

Seperti yang dijelaskan sebelumnya, bahwa kriteria atau ciri-ciri dari bisnis Multi Level Marketing yang sesuai dengan syariah di Indonesia sendiri diatur dalam fatwa MUI nomor 75/DSN-MUI/VII/2009 tentang pedoman Penjualan Langsung Berjenjang Syariah (PBLS) yang kriterianya yaitu sebagai berikut: (1). Adanya obyek transaksi riil yang diperjual belikan berupa barang atau produk jasa. PT. Harmoni Dinamik Indonesia adalah perusahaan Multi Level Marketing yang bergerak pada bidang produk suplemen makanan yang berasal dari proses hasil perlebahan yang berguna untuk menjaga kesehatan tubuh secara keseluruhan dan mengobati berbagai macam penyakit. Transaksi yang dilakukan pihak perusahaan atau anggota dengan konsumen adalah transaksi murni penukaran atas manfaat. (2). Produk yang dipasarkan harus halal, thayib (berkualitas), dan menghindari syubhat. Dari ketentuan diatas yakni mengenai sifat dari produk yang dijual, bahwa PT. Harmoni Dinamik Indonesia (HDI) menjual produk yang berasal dari perlebahan, yakni berupa madu, royal jelly, propolis dan bee pollen. Produk-produk tersebut sudah lama digunakan manusia sebagai bahan makanan, untuk pengobatan, dan untuk menjaga kesehatan tubuh manusia secara keseluruhan sejak ribuan tahun yang lalu. Dan untuk akreditasi produknya sendiri sudah mendapatkan sertifikasi halal dari Badan POM RI, untuk produk impor telah mendapat sertifikasi halal dari The Islamic And Nutrition Council of America (IFANCA) pada tanggal 15 Oktober 2009, sudah mendapatkan sertifikat anti-doping dari KAN (Komite Akreditasi Nasional), terdaftar dalam APLI (Asosiasi Penjualan
Langsung Indonesia), dan sudah bergabung pada APSKI (Asosiasi Pengusaha Suplemen Kesehatan Indonesia). ${ }^{19}$ Dari penjelasan diatas, dapat disimpulkan bahwa produk dari PT. Harmoni Dinamik Indonesia (HDI) ialah halal, tayib,dan tidak mengandung unsur syubhat. (3) Sistem akadnya harus memenuhi kaidah dan rukun jual beli sebagaimana yang terdapat dalam hukum Islam.Akad ialah suatu perbuatan yang sengaja dibuat oleh dua orang atau lebih berdasarkan keridhaan masing-masing, maka timbul bagi kedua belah pihak hak dan ijtihad yang diwujudkan oleh akad tersebut. $^{20}$ Dan untuk rukun jual beli, jumhur ulama bersepakat bahwa rukun dari jual beli ada 4, yaitu : (a) Orang yang berakad, (b) Sighat (ijab dan kabul), (c) Ada barang yang dibeli, (d) Ada nilai tukar pengganti barang. ${ }^{21}$

Dari penjelasan sebelumnya terkait praktik bisnis $M L M$ di HDI, peneliti dapat menyimpulkan bahwa akad atau perjanjian yang terjadi antara konsumen dan pihak perusahaan terjadi atas dasar keinginana dan kerelaan masing-masing pihak, tidak ada yang dirugikan, dan keduanya sama-sama mendapatkan keuntungan dari hal tersebut. Dalam jual beli, proses ini digambarkan dengan penjual yang mendapatkan uang, dan pembeli mendapatkan barang.

Selanjutnya mengenai rukun jual beli. Berdasarkan pengamatan peneliti terkait tentang transaksi yang dilakukan oleh pihak perusahaan dan konsumen, untuk empat poin dari rukun jual beli tersebut semuanya terpenuhi. Untuk perjanjian dilakukan secara jelas, yakni anggota HDI menerangkan apa-apa saja yang menjadi peraturan dari perusahaan serta penjelasan lain terkait dengan produk dan pembagian keuntungan. Untuk produk pun sama, macam-macam produk semuanya tersedia di stokis Cirebon, semua produknya nyata ada beserta manfaatnya masing-masing, untuk

\footnotetext{
${ }^{19}$ Enterpriser Kit, Bab Produk Kami, PT. Harmoni Dinamik Indonesia, 5-6.

${ }^{20}$ Sohari Sahrani dan Ru'fah Abdullah, Fikih Muamalah (Bogor: Ghalia Indonesia, 2011), 43.

${ }^{21}$ Sohari Sahrani dan Ru'fah Abdullah, Fikih Muamalah, 67.
} 
proses transaksi jual beli semua anggota mengambil produk di stokis, tidak ada sistem stok barang dari para anggota, ini menjaga agar produk HDI tidak dipalsukan oleh oknum lain. (4). Tidak ada upaya untuk melakukan mark up harga barang yang melampaui batas kewajaran (misal dua kali lipat), sehingga anggota terzalimi dengan harga yang sangat mahal, tidak sepadan dengan kualitas dan manfaatnya. Terkait kriteria tersebut mengenai harga dari produk $M L M$, peneliti mewawancarai salah satu konsumen produk HDI namun belum menjadi anggota (tidak mendaftar sebagai member) konsumen tersebut bernama Leli Lailatussholihah, ${ }^{22}$ ia berkomentar terkait harga dari produk HDI, yakni ia mengatakan: "Memang produk MLM terkenal dengan harganya yang mahalmahal ya, tapi menurut aku untuk produk HDI ini sesuai sih, harga dengan isi produk dan manfaat itu sudah sesuai. Memang untuk kalangan yang awam akan manfaat produknya dengan nominal harga segitu pasti akan bilang mahal. Tapi kalau sudah beli, sudah dirasa manfaatnya, harga segitu sudah sebanding. Soalnya kalau produk HDI itu biasanya kemasannya kecil kaya yang aku pakai aloe propolis cream itu terbilang kecil dengan harga segitu, tapi ternyata kalau sudah dipakai, pemakaiannya tuh sedikit aja udah cukup, jadi satu krim itu bisa tahan 5-6 bulanan bahkan lebih".

Berdasarkan penelitian yang sudah dilakukan, peneliti menemukan sesuatu yang berbeda dari sebuah acara seminar kesehatan yang diselenggrakan oleh HDI, yakni seminar kesehatan rutin setiap bulan yang dilakukan oleh pihak HDI dengan menentukan tema penyakit tertentu dalam pembahasannya. Seminar tersebut dinamakan Product Special Meeting, di HDI acara tersebut dikenal dengan istilah PSM. Pesertanya berisikan karyawan HDI, anggota HDI, masyarakat umum, dan juga pasien atau konsumen HDI yang berhasil sembuh dan dengan sukarela memberikan

\footnotetext{
${ }^{22}$ Wawancara dengan Leli Lailatussholihah Konsumen HDI, pada tanggal 07 Februari 2017.
}

kesaksian testimoni atas kesembuhannya. Dengan pembicara dokter konsultan HDI stokis Cirebon yakni dr. H. Alamsyah BN Hatta. Diantara penyakitnya yang berhasil sembuh yaitu radang paru-paru, epilepsi, demam berdarah, maag kronis, jerawat radang, asma, penyakit kuning, infertility,stroke, gagal ginjal dan banyak penyakit lainnya. Pasien di datangkan langsung dan diberikan kesempatan untuk bercerita dari awal mengenal HDI hingga mengkonsumsinya. Dari reaksi konsumen sendiri, mereka merasa harga yang sudah ditetapkan dan manfaatnya sudah sangat sepadan. $^{23}$ (5). Struktur manajemennya memiliki Dewan Pengawas Syariah (DPS) yang terdiri dari para ulama yang memahami masalah ekonomi. Untuk PT. Harmoni Dinamik Indonesia sendiri saat ini sedang menuju proses sertifikasi halal dari MUI. Dokter Alamsyah mengatakan: "Untuk sertifikasi halal masih dalam proses. Saat ini, khusus di stokis Cirebon sendiri akan kita buat lebih syariah, khususnya dari segi dokter konsultan. Di Cirebon akan tersedia dua dokter konsultan HDI, yang pertama itu saya, lalu yang kedua ada dokter Nunung. Jadi nanti pasien laki-laki akan konsultasi sama saya, dan pasien perempuan sama dokter Nunung", 24

Jadi, dari pernyataan pemilik stokis HDI Cirebon tersebut, dapat disimpulkan oleh peneliti bahwa saat ini PT. Harmoni Dinamik Indonesia sedang menuju menjadi MLM syariah, dan khusus untuk stokis Cirebon sendiri sedang dalam perbaikan sistem menjadi lebih syariah dengan menyediakan dua dokter konsultan yakni dokter laki-laki dan perempuan. (6). Formula insentif harus adil, tidak menzalimi downline dan tidak menempatkan upline hanya sebagai anggota yang menerima pasif income tanpa bekerja.Untuk permasalahan terkait insentif, peneliti telah melakukan wawancara dengan seorang anggota dari

\footnotetext{
${ }^{23}$ Acara Seminar PSM (Product Special Meeting) Hotel Cordela, 24 Desember 2017.

${ }^{24}$ Wawancara dengan Alamsyah BN Hatta, Pemilik Stokis HDI Cirebon, pada tanggal 07 Maret 2018.
} 
HDI yang bernama Siti Salamah, beliau adalah member HDI yang sudah menduduki peringkat enterpriser leader. Berikut tanggapan beliau terkait tentang sudah adil atau belumkah pembagian insentif di HDI ini: ${ }^{25}$ "Sudah adil, bahkan adil banget. HDI benar-benar menghargai setiap usaha dari para enterpriser nya ya. Bisa dibilang sudah transparan lah pembagian bonusnya, karena bener-bener sesuai sama yang tertera di bisnis plan nya, bisnis plan kan sudah dijelaskan ya dari awal semenjak kita memutuskan buat gabung, sudah tercatat dan tertera, dan memang pada kenyataannya sudah sesuai dengan apa yang di perjanjikan".(7). Pembagian bonus harus mencerminkan usaha masing-masing anggota. Berlanjut dari poin sebelumnya yakni tentang keadilan dalam pembagian bonus, terkait hal ini peneliti pun menanyakan tentang bonus yang diberikan pihak perusahaan kepada anggota apakah sudah sesuai dengan kinerja yang dilakukannya. Responden pun menjawab:"Sudah sesuai dengan kinerja setiap anggota. Jadi begini, di HDI itu ga ada sistem lebih menguntungkan anggota yang diatas, jika yang diatasnya ini ga aktif, atau ga ada kerjanya atau bisa dibilang gatutup poin. Enaknya di HDI seperti ini, jadi kita yang baru bergabung bisa berada di atas upline kita".Beliau pun menambakan bahwa kunci berada di HDI ini adalah kerja keras, mustahil bisa sukses di HDI tetapi anggota tersebut malas. (8) Tidak ada eksploitasi dalam aturan pembagian bonus antara orang yang awal menjadi anggota dengan yang akhir (belakangan).Menurut seorang enterpriser leader di HDI yaitu Siti Salamah, bahwa semua bisnis Multi Level Marketing itu adalah sama. Yang membedakan adalah sistem yang dijalankan dan aturan dari masing-masing perusahaan itu sendiri. Selama ini, anggapan yang tidak baik tentang $M L M$ menurut beliau adalah akibat dari penyalahgunaan sistem oleh pihak yang

\footnotetext{
${ }^{25}$ Wawancara dengan Siti Salamah, enterpriser leader, pada tanggal 09 Februari 2018.
}

ingin memanfaatkan adanya $M L M$ dengan hal yang tidak baik.

Untuk pernyataan bahwa Multi Level Marketing hanya menguntungkan pihak yang diatas, beliau menjelaskan bahwa tidak ada satu pekerjaan pun yang tidak menguntungkan pihak yang diatas, karyawan pun sama menguntungkan pihak yang diatas. Beliau menjelaskan bahwa statement tersebut memiliki dua makna, yakni positif dan negatif. Makna positifnya yaitu, memang menguntungkan pihak yang diatas, tetapi dengan syarat orang yang diatas tersebut aktif, bekerja keras, dan yang lebih penting ialah orang yang diatas tersebut bisa tutup poin setiap bulannya, karena syarat untuk mendapatkan bonus adalah anggota yang bisa mencapai target (tutup poin). (9). Bonus yang diberikan harus jelas angka nisbahnya sejak awal.Dari hasil wawancara diatas, peneliti dapat menyimpulkan bahwa pembagian bonus pada PT. Harmoni Dinamik Indonesia sudah jelas dan tertera pada enterpriser kit atau diskit yang sudah dibagikan perusahaan kepada member. Member sudah menyepakati dengan sebelumnya dijelaskan terlebih dahulu oleh seorang upline, dan berdasarkan keterangan dari salah satu anggota HDI bahwa perusahaan sudah menepati perjanjian tersebut dengan cara membagikan bonus sesuai dengan apa yang tertera. (10). Tidak menitikberatkan kepada barang-barang tersier ketika umat masih bergelut dengan pemenuhan kebutuhan primer.

Kebutuhan manusia diklasifikasikan menjadi tiga jenis yaitu primer, sekunder, dan tersier. Kebutuhan primer adalah kebutuhan pokok (primary) yang dibutuhkan oleh manusia. Jika kebutuhan primer ini tidak terpenuhi, maka akan menggangu berlangsungnya kehidupan manusia tersebut. Berikut adalah kebutuhankebutuhan yang termasuk dalam kebutuhan primer yaitu sandang (pakaian), pangan (makanan), papan (tempat tinggal), keluarga, teman, pendidikan, informasi, pengetahuan, pekerjaan, kasih sayang, hubungan, privasi, kesehatan, keselamatan, keamanan, ketentraman, dihargai dan 
menghargai, menunjukkan kemampuan, identitas, mencintai dan dicintai. $^{26}$

Kebutuhan tersier ialah kebutuhan tingkat ketiga, artinya kebutuhan ini merupakan kebutuhan yang dapat dipenuhi apabila kebutuhan primer dan sekunder telah terpenuhi, bisa diartikan pula baha kebutuhan tersier ini adalah kebutuhan yang mewah, kebetuhan yang tidak terlalu genting dan berpengaruh pada keberlangsungan hidup manusia. Contohnya yaitu perhiasan, aksesoris mewah, kendaraan mewah, rumah mewah, wisata ke luar negeri, baju branded, investasi.

Dari penjelasan diatas, dapat kita tarik kesimpulan bahwa produk dari PT. Harmoni Dinamik Indonesia ialah termasuk dalam kelompok kebutuhan primer, karena produk yang dipasarkan ialah berupa suplemen makanan, yang sangat bermanfaat bagi kesehatan manusia serta mampu membantu penyembuhan serta pemulihan berbagai macam penyakit. Saat ini, kebutuhan akan faktor kesehatan menjadi hal pokok yang dipenuhi oleh masyarakat, mengingat kesehatan sangat berpengaruh terhadap keberlangsungan hidup manusia serta pemenuhan aktivitasnya. (11). Cara penghargaan kepada mereka yang berprestasi tidak boleh mencerminkan sikap hura-hura dan pesta pora karena sikap tersebut tidak sesuai dengan syariah.Berdasarkan enterpriser kit HDI yang peneliti baca, tertera beberapa ketentuan terkait promo trip HDI. Promo trip HDI ini adalah sebuah rangkaian acara liburan yang diadakan perusahaan untuk anggota HDI yang telah memenuhi target yang telah ditentukan oleh perusahaan, tujuan perjalannanya ialah trip ke Singapura, China, hingga Eropa secara gratis, bahkan pergi Umroh. Terkait hal tersebut, peneliti meminta tanggapan dari pihak HDI cabang Cirebon, terkait pemberian bonus tersebut. Beliau mengatakan:"Bonus seperti itu menurutku tidak berlebihan atau disebut hura-hura dan pesta pora, karena dibalik bonus itu ada

\footnotetext{
12 Februari 2018.
}

syarat yang harus anggota penuhi, dan menurutku syarat tersebut tidak mudah, didalamnya mengandung unsur omzet, jaringan, dan ketepatan waktu. Jadi, sifat pemberian bonus yang berlebihan tersebut gugur dengan adanya syarat tersebut. Di HDI semua suku, ras, golongan, profesi, status semua bisa mendapatkan bonus tersebut dengan syarat memenuhi ketentuannya".

(12). Perusahaan Multi Level Marketing harus berorientasi kepada kemaslahatan ekonomi umat. Dari beberapa pengamatan, peneliti menilai bahwa keberadaan perusahaan PT. Harmoni Dinamik Indonesia ini khususnya di wilayah Cirebon sangat sangat membantu keadaan ekonomi masyarakatnya. Keberadaan HDI sangat dimanfaatkan oleh masyarakat untuk memperoleh penghasilan tambahan, seperti bisnis sampingan bagi karyawan, mahasiswa, ibu rumah tangga, bahkan beberapa profesi besar seperti dokter, dan lain-lain. Jadi, selain bermanfaat bagi kesehatan tubuh, HDI juga memberikan manfaat untuk permasalahan ekonomi masyarakat.

Dari penjelasan diatas terkait kriteria MLM Syariah menurut DSN-MUI, peneliti menganalisa bahwa sistem yang sudah diterapkan oleh perusahaan HDI selama ini sudah sangat baik, sudah sesuai dengan hukum yang berlaku dalam syariah dan hukum positif, namun yang menjadi faktor $M L M$ ini belum bersertifikat halal, ialah karena faktor internal dari personal perusahaan sendiri, salah satu faktor tersebut ialah kurangnya kesadaran dari pihak pejabat tinggi dan beberapa owner stokis HDI di cabang lainnya akan urgensi dari ke-syariah-an sebuah perusahaan Multi Level Marketing itu sendiri.

\section{Analisis Praktik Bisnis Multi Level Marketing dalam Perspektif Hukum Positif}

Berdasarkan dari beberapa ketentuan pokok yang menjadi acuan dari bisnis Multi Level Marketing yang telah dijelaskan sebelumnya pada bagian bisnis MLM dalam hukum positif, yakni terdapat dua belas ketentuan 
pokok. Peneliti menyimpulkan bahwa semua syarat pokok di atas sudah dipenuhi oleh pihak PT. Harmoni Dinamik Indonesia sebagai perusahaan yang bersistemkan direct selling atau bisnis jaringan, berdasarkan pada beberapa penelitian dan wawancara yang telah dilakukan oleh peneliti.

Berkaitan tentang pembinaan dan pelatihan untuk meningkatkan kemampuan dan pengetahuan mitra usaha, berikut adalah daftar pelatihan-pelatihan yang diselenggarakan perusahaan untuk meningkatkan kemampuan anggotanya, diantaranya yaitu: (1). BEST (Billionaires Executive Training System). Billionaires Executive Training System (BEST) adalah training besar tingkat nasional yang diselenggarakan dua kali dalam setahun oleh Billionaires dan High-Desert, yaitu pada bulan Maret dan Agustus atau September. Acara BEST diselenggarakan di Surabaya Supermall Convention Center dan ditujukan bukan hanya kepada mereka yang telah bergabung menjadi Enterpriser HDI tapi juga khalayak umum. Selama tiga hari berlangsungnya acara tersebut, para peserta akan mendapatkan beragam materi yang bermanfaat untuk menjalankan bisnis HighDesert serta meningkatkan kualitas hidup mereka. (2). BIG (Billionaires Instructor Gathering). Billionaires Instructor Gathering (BIG) merupakan sebuah acara yang diadakan oleh Billionaires Support System yang bertujuan membangun fondasi yang kokoh bagi para leader.Hanya enterpriser dengan peringkat leader ke atas dengan omzet grup minimal 20.000.000 BV yang dapat menghadiri acara BIG. Melalui acara ini diharapkan lahir pemimpinpemimpin baru yang akan menjadi bukti, panutan, dan landasan yang kokoh bagi setiap orang yang mau mencapai kesuksesan. Acara BIG biasa diadakan pada hari kerja.

(3). BMW (Billionaires Meeting Weekend). Pelatihan di alam terbuka yang sifatnya simulasi Billionaires Meeting Weekend (BMW) merupakan sebuah training yang diadakan oleh billionaires dan didukung oleh manajemen High-Desert.
Acara yang diadakan per wilayah di seluruh Indonesia ini berlangsung selama dua hari pada akhir pekan. Peserta diajak mengikuti berbagai simulasi menarik yang merupakan latihan untuk menjalankan bisnis HighDesert dengan benar.Acara ini sangat bermanfaat bagi mereka yang baru bergabung menjadi enterpriser High-Desert. Peserta yang baru pertama kali mengikuti acara ini akan diberikan pelatihan The Diamond, yaitu simulasi yang akan menunjukkan peserta bagaimana cara menjalankan bisnis dengan benar hingga mampu mencapai peringkat Diamond Leader. (4). RTS (Road To Succes). Road To Success (RTS) adalah sebuah training yang ditujukan bagi khalayak umum dan para enterpriser HDI di kota-kota di seluruh Indonesia. Seminar yang diadakan dua kali dalam satu tahun ini akan menampilkan kisah liku-liku para perjalanan Enterpriser HDI yang telah sukses dalam menjalankan bisnisnya.

(5). BOM (Bussines Opportunity Meeting). Business Opportunity Meeting (BOM) adalah pertemuan peluang usaha yang diadakan oleh support system billionaires bekerja sama dengan stokis High-Desert. Business Opportunity Meeting (BOM) adalah pertemuan yang membahas peluang usaha. Pertemuan ini diadakan oleh Business Support System bekerja sama dengan stokis HighDesert di seluruh Indonesia. Acara ini dikemas dalam bentuk seminar kesehatan dan diselenggarakan secara rutin dua kali dalam sebulan. Peserta diberi materi tentang bisnis High-Desert secara umum.Setiap acara BOM selalu memiliki tema yang mengangkat masalah kesehatan. Tema yang dibahas biasanya seputar penyakit tertentu, seperti stroke, kanker, hepatitis, dan diabetes. (6). PSM (Product Special Meeting). Product Special Meeting (PSM) adalah pertemuan khusus yang menyajikan penjelasan lengkap tentang produk-produk High-Desert. Acara PSM bertujuan untuk memotivasi setiap orang untuk hidup sehat dan tetap menjaga kualitas hidupnya dengan mengonsumsi produk-produk High-Desert yang berkualitas. Di acara ini, peserta acara 
akan mendapat penjelasan tentang bahan, kandungan di seluruh produk High-Desert serta manfaat dari produk-produk tersebut. Untuk mendukung penjelasan produk, diadakan pula acara testimoni yang menampilkan kesaksian orang-orang yang telah mengonsumsi produk-produk HighDesert dan merasakan langsung manfaatnya dalam membantu penyembuhan penyakitnya. $^{27}$

Berdasarkan analisa peneliti terkait uraian diatas tentang hukum bisnis Multi Level Marketing dalam perspektif hukum Islam dan hukum positif pada perusahaan PT. Harmoni Dinamik Indonesia. Peneliti menganalisa bahwa dari segi syarat dan ketentuan yang berlaku antara hukum Islam dan hukum positif pada perusahaan tersebut sudah terpenuhi dengan baik, hanya saja dari segi ke-legalan $M L M$ syariah pada HDI belum menguat karena masih dalam proses pengajuan ke DSN-MUI, sehingga belum tersedianya struktur manajemen DSN-MUI sebagai pengawas di perusahaan tersebut. Inti dari bisnis Multi Level Marketing yang baik dan sesuai dengan hukum syariah dan hukum positif ialah dapat dilihat dari segi prosedur atau cara perekrutan anggota (apakah mewajibkan untuk membeli produk bahkan paket atau tidak), dari segi bonus, pembagian keuntungan (sesuai kinerja atau hanya menguntungkan yang diatas), dari segi kehalalan produk dan keberadaannya nyata, harga barang yang wajar, program pemasaran (marketing plan) yang jelas dan transparan.

\section{KESIMPULAN}

Berdasarkan hasil penelitian di atas, dapat disimpulkan menjadi dua, yaitu pertama, Sistem Multi Level Marketing yang diaplikasikan oleh perusahaan tersebut adalah sistem network murni atau biasa dikenal dengan sistem matahari, yakni suatu sistem dimana anggota diberikan kebebasan untuk mengembangkan jaringan. Ciri utama

${ }^{27}$ www.hdindonesia.com. Diakses pada tanggal 12 Februari 2017. Dan wawancara dengan Siti Salamah enterpriser leader, pada tanggal 09 Februari 2018. dari sistem ini adalah menerapkan sistem tutup poin tiap bulannya dan posisi downline dapat setara bahkan bisa lebih tinggi dari upline nya.

Dan yang Kedua, status hukum dari bisnis Multi Level Marketing dalam perspektif hukum Islam yakni berdasarkan fatwa DSN-MUI, terdapat dalam fatwa MUI nomor 75/DSN-MUI/VII/2009 tentang pedoman Penjualan Langsung Berjenjang Syariah (PBLS) yang didalamnya memuat 12 kriteria bisnis Multi Level Marketing yang sesuai dengan syariah. Sedangkan dalam hukum positif diatur dalam UU No. 7 Tahun 2014 oleh Kementerian Perindustrian dan Perdagangan tentang perdagangan yang didalamnya termuat tentang ketentuan umum distribusi barang, dan menurut Peraturan Menteri Perdagangan RI No. 13/M-DAG/PER/3/2006 tentang tata cara surat izin usaha langsung.Pada dua status hukum (hukum Islam dan positif) tersebut, pada intinya membahas peraturan yang sama yakni mencakup produk yang baik dan halal, komisi yang jelas, marketing plan yang jelas, harga yang sesuai dengan kualitas dan batas kewajaran, keadilan dalam pembagian bonus, poin selebihnya adalah ketentuan tentang keharusan dari masing-masing wilayah hukum. Secara hukum syariah dan positif sistem yang diaplikasikan oleh perusahaan PT. Harmoni Dinamik Indonesia khususnya cabang Cirebon sudah sesuai dengan hukum Islam dan hukum positif. Namun, kelegalan syariah nya belum terdaftar dalam DSNMUI karena beberapa faktor internal dari perusahaan tersebut, salah satunya ialah kurangnya kesadaran dari personal dan pemilik stokis cabang lainnya akan pentingnya label syariah dalam bisnis ini, sehingga sampai saat ini ke-syariah-annya belum juga terproses dalam DSN-MUI . 


\section{DAFTAR PUSTAKA}

Agustianto. MLM dalam Perspektif Syari'ah, dalam www.iaei-pusat.org. Diakses pada tanggal 19 April 2017.

Departemen Agama RI. Al-Qur'an dan Terjemahnya. Bandung: Sinar Baru Algensindo, 2010.

Dewi, Gemala, Wirdyaningsih dan Yeni Salma Barlinti, Hukum Perikatan Islam di Indonesia. Jakarta: Kencana, 2006.

Fatwa DSN-MUI tentang 75 Pedoman Penjualan Langsung Berjenjang Sariah (PLBS), dalam www.dsnmui.or.id. Diakses pada tanggal 19 April 2017.

Harefa, Andreas. Multi Level Marketing. Jakarta: PT. Gramedia Pustaka Utama, 1999.

http://www.kemendag.go.id/undangundang-no-7-tentangperdagangan. Diakses pada tanggal 19 April 2017.

Jauhari, Sofwan. MLM Syariah: Buku Wajib Wirausahawan Muslim Praktisi MLM Syariah. Jakarta: Mujaddidi Press, 2013.

Kuncoro, Anis Tyas. "Konsep Bisnis Multi Level Marketing Dalam Perspektif Ekonomi Syariah", Jurnal UNISSULA, Vol. XLV, No.119 (Nopember, 2009).

Muslich, Ahmad Wardi. Fiqh Muamalah. Jakarta: Amzah, 2013.

Sahrani, Sohari dan Ru'fah Abdullah. Fikih Muamalah. Bogor: Ghalia Indonesia, 2011.

Sudarto. Metodologi Penelitian Filsafat. Jakarta: Raja Grafindo Persada, 1995.

Sugiono. Memahami Penelitian Kualitatif. Bandung: Alfabeta, 2008.

Wahyudi, Firman. "Multi Level Marketing dalam kajian Fiq Muamalah", Jurnal Al-Banjari, Vol. 13, No. 2 (Desember, 2014).

www.eduspensia.id. Diakses pada tanggal 12 Februari 2018.

www.hdindonesia.com. Diakses pada tanggal 12 Februari 2017.
Yusuf, Ahmad Teguh Wibowo. Dialog MLM Syariah. Jakarta: Ahad-Net, 2002. 